I 314

\title{
DNAチップを用いたトリクロロエチレンの経ロ投与による 遭伝子発現变化の解析
}

\author{
佐野 有理 ${ }^{1}$ 、吉岡 範幸 ${ }^{1} 、$ 中島 宏 ${ }^{1}$ 、衛藤 憲人 1、西脇 祐司 ${ }^{1}$ 、武林 亨 1 、 \\ 大前 和幸 1 \\ ${ }^{1}$ 慶応大学 医学部 衛生学公采衛生学教室
}

〈目的＞前回我々は、マウスとラットに対してトリクロロエチレンを経口投与し、その遺伝子発現変化の種 差を DNA チップで観察した結果について報告した。その際の実験系は c RNA の段階で各群 4 匹分のサンプ ルを混合した pooled sample を用いたため、コントロール群、曝露群のサンプル数は各曝露時点において $\mathrm{n}=$ 1 となり、統計学的解析に不都合が生じた。今回我々は、経口投与実験後に凍結保存していた肝蔵から新た にmRNA を抽出し、DNA チップに再ハイブリダイゼーションさせて、各曝露時点におけるコントロール群 と曝露群のそれぞれ $\mathrm{n}=4$ の遭伝子発現プロファイルを得た。このデータの解析結果を報告する。なお、TCE はマウスでは肝細胞癌を発生させるが、ラットとヒトでは肝細胞癌の発生は報告されていないという種差が 存在する。<方法>B6C3F1 マウス (8 週㱓、雄)、及びSD ラット (8 週龄、雄)の 4 匹ずつを 4群に分け、 トリクロロエチレンをコーン油に溶解させて $1500 \mathrm{mg} \mathrm{TCE} / \mathrm{k} \mathrm{g}$ 体重で経口投与を行った。曝露条件は以下の 通りである。1) corn oil のみ単回経口投与 18 時間後肝臟摘出。2) TCE 単回経口投与 18 時間後肝臟摘出。 3) corn oil のみ 2 週間反復経口投与 18 時間後肝䑏摘出。4) TCE 2 週間反復経口投与 18 時間後肝灆摘出。 各群 4 匹ずつの肝葴より total RNA を抽出し c DNA を合成した。 c DNA はビオチン化標識 $\mathrm{c}$ RNA に転写後、 Affymetrix 社の DNA チップ(Murine Genome U74v2 : 12488 個のマウスのプローブを含む。Rat Genome U34A： 8799 個のラットのプローブを含む。) へハイブリダイゼーションした。数值化されたデータは各チップ間で の比較を可能とするために、シグナル值の分布を一致させるノーマライゼーションを行い、その上でべイズ の理論を用いてコントロール群と鬨露群の間で有意差のある発現変化を示したプローブを検出した。またこ の遭伝子発現プロファイルは Gene Spring Ver7.0 (Agilent 社)、及びNIH が無偵で配信している Database for Annotation, Visualization and Integrated Discovery (DAVID、http://apps1.niaid.nih.gov/david)等を用いてデータマ インニングや機能解析を行なった。〈結果と考察〉今回有意差があるとして検出されたプローブを、n=1の pooled sample に対して cross gene error model を用いて統計解析を行ない，有意差があるとして前回検出され たプローブと比較すると、両者で共通に検出されたプローブの数は少なかった。今回得られた有意差がある プローブの機能を解析したところ、マウスではアポトーシスを抑制する方向に遺伝子発現が変化していたが、 ラットではこのような変化は観察されないという特幑が得られた。くまとめ>Replicate を設けることで解析 の適確性が增し、遺伝子発現レベルでの生体反応の種差が明らかとなった。 